\title{
OPEN Publisher Correction: Enabling Covert Body Area Network using Electro-Quasistatic Human Body Communication
}

\author{
Debayan Das 1 , Shovan Maity (D), Baibhab Chatterjee \& Shreyas Sen $(\mathbb{1})$ \\ Correction to: Scientific Reports https://doi.org/10.1038/s41598-018-38303-x, published online 11 March 2019 \\ The publication date was omitted from the original PDF version of this Article. This error has now been corrected \\ in the PDF version; the HTML version was correct from the time of publication.
}

\begin{abstract}
(i) Open Access This article is licensed under a Creative Commons Attribution 4.0 International C. License, which permits use, sharing, adaptation, distribution and reproduction in any medium or format, as long as you give appropriate credit to the original author(s) and the source, provide a link to the Creative Commons license, and indicate if changes were made. The images or other third party material in this article are included in the article's Creative Commons license, unless indicated otherwise in a credit line to the material. If material is not included in the article's Creative Commons license and your intended use is not permitted by statutory regulation or exceeds the permitted use, you will need to obtain permission directly from the copyright holder. To view a copy of this license, visit http://creativecommons.org/licenses/by/4.0/.
\end{abstract}

(c) The Author(s) 2020 